\title{
AUTOMATED FLOW-INJECTION METHOD FOR CADMIUM DETERMINATION WITH PRE- CONCENTRATION AND REAGENT PREPARATION ON-LINE
}

\author{
María S. Di Nezio, Miriam E. Palomeque and Beatriz S. Fernández Band* \\ Department of Chemistry, FIA Laboratory, Universidad Nacional del Sur, 8000-Bahía Blanca, Argentine
}

Recebido em 5/1/04; aceito em 12/7/04; publicado na web em 5/11/04

\begin{abstract}
AUTOMATED FLOW INJECTION METHOD FOR CADMIUM DETERMINATION WITH PRE-CONCENTRATION AND ONLINE REAGENT PREPARATION. The spectrophotometric determination of Cd(II) using a flow injection system provided with a solid-phase reactor for cadmium preconcentration and on-line reagent preparation, is described. It is based on the formation of a dithizone-Cd complex in basic medium. The calibration curve is linear between 6 and $300 \mu \mathrm{g} \mathrm{L}^{-1} \mathrm{Cd}$ (II), with a detection limit of $5.4 \mu \mathrm{g} \mathrm{L}^{-1}$, an RSD of $3.7 \%$ (10 replicates in duplicate) and a sample frequency of $11.4 \mathrm{~h}^{-1}$. The proposed method was satisfactorily applied to the determination of $\mathrm{Cd}(\mathrm{II})$ in surface, well and drinking waters.
\end{abstract}

Keywords: Cd (II); preconcentration; FIA.

\section{INTRODUCTION}

Heavy metals are considered to be one of the main sources of pollution for the environment, since they have an important effect on its ecological quality ${ }^{1}$. The human activity increases the contamination levels in the environment.

Cadmium is a severe toxic metal and therefore needs to be frequently monitored in several matrices. It is widely used in special alloys, pigments, coatings stabilisers and in rechargeable nickelcadmium batteries. The major route for cadmium intake is its ingestion. This is largely due to the presence of trace levels of cadmium in foodstuffs of natural origin or the use of phosphate fertilisers and sludge on agricultural soils.

It has been well established that the exposure to an excess of cadmium produces adverse health effects on human beings. Cadmium can be incorporated to the blood by absorption in stomach or intestines after food or water ingestion, or by absorption on lungs after inhalation. It mainly accumulates in the kidney and at high levels it can lead to serious kidney failure.

Several analytical techniques such as flame atomic absorption spectrometry (FAAS) ${ }^{2,3}$, inductively coupled plasma atomic emission spectrometry (ICP-AES) ${ }^{4}$ and inductively coupled plasma mass spectrometry (ICP-MS) ${ }^{5}$ are available for the determination of trace metals with enough sensitivity for the most applications. However, the determination of trace metal ions in natural waters is difficult owing to different factors, particularly their low concentrations and matrix effects. Usually, they need matrix separation procedures such as solvent extraction, ion exchange or precipitation to eliminate the matrix or the source of the interfering ions.

Absorption molecular spectroscopy (UV-V) methods were used for cadmium determination ${ }^{6-9}$. Spectrophotometric detection even is a widely used technique, because its simplicity, lower cost of instrumentation, and usually is precise and accurate. Dithizone, the old and known reagent, is still used as chromogenic reagent for heavy metals determination, with the classical extraction of the analyte in organic medium. The use of this reagent in aqueous/surfactant medium has been reported ${ }^{6}$ to prevent the use of chlorinate solvents. However, the reagent in this conditions is unstable to light exposure,

*e-mail: usband@criba.edu.ar so there is not evidence in the literature of its application in other analytical determinations.

The spectrophotometric method proposed in this paper presents different advantages such as a wide linear range, low detection limit and good sensitivity and selectivity compared with other spectrophotometric methods ${ }^{8,9}$, and an acceptable sample throughput. Also the automatization attained in this analytical method makes it easy to carry out.

The aim of this paper was to propose an alternative FIA method for spectrophotometric determination of Cd(II). The method is based on Cd-dithizone complex formation in basic medium. As this analytical method was applied in waters samples, a preconcentration step was implemented on-line in order to decrease the detection limit. The Dithizone reagent was on-line prepared in aqueous/surfactant medium by using a mini-column filled with solid reagent.

\section{EXPERIMENTAL PART}

\section{Apparatus}

An UV-V Hewlett Packard 8452A diode array spectrophotometer with a Hellma 178-712Q flow cell with an inner volume of $8 \mu \mathrm{l}$ was used. The propulsion system consisted of two Gilson Minipuls 3 peristaltic pumps. Rheodyne 5041 and 5011 injection valves were used. The flow system was made of PTEF tubing of 0.5 i.d.

\section{Mini-column preparation}

The ion exchange mini-column was prepared by packing a glass tube (length: $3.0 \mathrm{~cm}$, i.d.: $4.0 \mathrm{~mm}$ ) with Dowex 1-X10 resin (50-100 mesh). The ends of the tubes were fitted with a piece of cigarette filter to keep the resin inside the tube.

\section{The Solid Reagent Column (SRC) preparation}

The SRC was prepared by using a dark Tygon ${ }^{\circledR}$ tube (length: $5 \mathrm{~cm}$; i.d.: $3 \mathrm{~mm}$ ) to avoid the photo-degradation of the reagent. It was packed with $50 \mathrm{mg}$ of dithizone and one of the ends of the tube was fitted with a piece of cigarette filter to keep the solid reagent inside the tube. 


\section{Reagents and solutions}

All reagents were of analytical-reagent grade. Solutions were prepared with ultra pure water $(18 \mathrm{M} \Omega)$.

A $2.003 \mathrm{~g} \mathrm{~L}^{-1}$ cadmium stock solution was prepared dissolving $0.4064 \mathrm{~g}$ of $\mathrm{CdCl}_{2} \cdot 2 \frac{1}{2} \mathrm{H}_{2} \mathrm{O}$ (Mallinckrodt) and making up to $100 \mathrm{~mL}$ with water. The cadmium calibration solutions were prepared from the stock solution.

The solution of $1 \times 10^{-3} \mathrm{~mol} \mathrm{~L}^{-1} \mathrm{NaOH}$ was prepared dissolving $0.04 \mathrm{~g}$ of $\mathrm{NaOH}$ (Merck) in $1000 \mathrm{~mL}$ of water.

The solution of $5 \%(\mathrm{v} / \mathrm{v})$ Triton $\mathrm{X}-100$ was prepared dissolving $50 \mathrm{~mL}$ of surfactant in $100 \mathrm{~mL}$ of $1 \mathrm{~mol} \mathrm{~L}^{-1} \mathrm{HCl}$, and then making up to $1000 \mathrm{~mL}$ with water.

\section{Samples}

Surface water samples from Colorado River (Paso Alsina, Río Negro State, Argentine), Paso Piedras Dike (Bahía Blanca, Buenos Aires State, Argentine); drinking water sample of Bahía Blanca (Buenos Aires State, Argentine); well water samples from San Cayetano (Buenos Aires State, Argentine) and Paso Piedras Dike (Bahía Blanca, Buenos Aires State, Argentine), were collected into plastic Van-Dorn bottles and stored at $4{ }^{\circ} \mathrm{C}$.

Before the analysis, they were equilibrated to a room temperature.

\section{Procedure}

The flow injection system is shown in Figure 1. The Dithizone reagent solution was on-line prepared when a stream of 5\% Triton $\mathrm{X}-100$ was passed through the SRC, the reagent stream merged with a dilution line of the same solvent in $\mathrm{R}_{1}$, to obtain a suitable concentration.

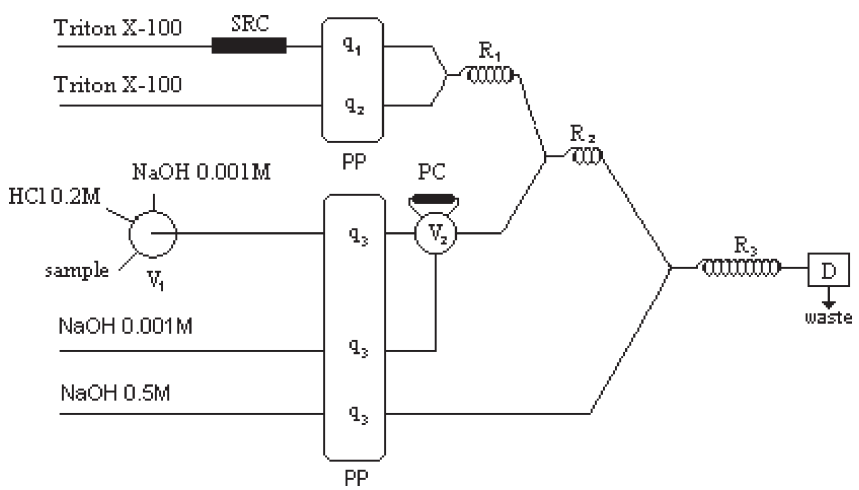

Figure 1. PP: peristaltic pump; $V_{1}$ : six way valve; $V_{2}$ : injection valve; $q_{1}$ : Triton $\mathrm{X}-100$ flow rate; $q_{2}$ : diluent flow rate; $q_{3}: \mathrm{HCl}$, sample and $\mathrm{NaOH}$ flow rates; SRC: solid reagent column; PC: preconcentration column; $R_{l}, R_{2}$ and $R_{3}$ : reactors; $D$ : detector; $W$ : waste

The preconcentration step was carried out using a mini-column packed with Dowex 1-X10 located in the valve $\mathrm{V}_{2}$ instead the sample loop. Before loading the mini-column, it was conditioned for the cadmium preconcentration with $0.2 \mathrm{~mol} \mathrm{~L}^{-1} \mathrm{HCl}$, which was passed through it for $2 \mathrm{~min}$. Then, the sample was loaded for $3 \mathrm{~min}$ (valve $\mathrm{V}_{2}$ in load position). After the loading time, a further washing with $0.2 \mathrm{~mol} \mathrm{~L}^{-1} \mathrm{HCl}$, for $30 \mathrm{~s}$, served to remove the sample still present in the lines and in the mini-column. Finally, $V_{1}$ and $V_{2}$ valves were simultaneously switched on and the retained metal was eluted with $10^{-3} \mathrm{~mol} \mathrm{~L}-1 \mathrm{NaOH}$.

This stream merged with the dithizone solution inside the reactor $\mathrm{R}_{2}$ and then with a $\mathrm{NaOH}\left(0.5 \mathrm{~mol} \mathrm{~L}^{-1}\right)$ stream to attain the optimum conditions for the Cd-Dithizone complex formation in the reactor $\mathrm{R}_{3}$. The signal was measured at $544 \mathrm{~nm}$.

\section{RESULTS AND DISCUSSION}

\section{Optimisation of chemical and FIA variables}

To yield the best performance of the developed manifold (the highest signal and the best reproducibility) chemical and FIA variables were optimised by the univariate method. For this purpose $150 \mu \mathrm{g} \mathrm{L}^{-1}$ of cadmium standard solution was used.

\section{Preconcentration system}

Dowex 1-X10 anion exchange resin was used to fill in the minicolumn for cadmium retention. This resin was washed with hydrochloric acid to ensure complete conversion to the chloride form ${ }^{10}$ and to remove iron impurity present in the commercial product. The hydrochloric acid concentration must be less than $2 \mathrm{~mol} \mathrm{~L}^{-1}$ to prevent the anionic iron-chloro complex formation which was adsorbed by the resin ${ }^{11}$. Also, the conditions to regenerate on-line the resin were studied, different concentrations of hydrochloric acid were tested between 0.1 to $0.5 \mathrm{~mol} \mathrm{~L}^{-1}$, the optimum value was $0.2 \mathrm{~mol} \mathrm{~L}^{-1}$.

The cadmium was retained in the resin as anionic chloro complex. Thus, samples were prepared in different concentrations of hydrochloric acid. These concentrations were tested between 0.2 and $3.0 \mathrm{~mol} \mathrm{~L}^{-1}$ and the optimum was $1.0 \mathrm{~mol} \mathrm{~L}^{-1}$.

Cadmium was successful elute with $\mathrm{NaOH}$ solution. Different alkaline solutions were tested between $10^{-4} \mathrm{~mol} \mathrm{~L}^{-1}$ to $0.5 \mathrm{~mol} \mathrm{~L}-1$; a fast and total elution was achieved with $\mathrm{NaOH} 10^{-3} \mathrm{~mol} \mathrm{~L}^{-1}$.

\section{FIA system}

Dithizone solution in aqueous medium showed to be highly unstable to light exposure and its preparation is very tedious and time consuming. So, it was prepared on-line by using a solid reagent column (SRC). A dark Tygon ${ }^{\circledast}$ tube was used as a column, which was filled with the Dithizone solid reagent.

The SRC was connected in the FIA system and a triton X-100 solution was passed through it. Since the amount of dithizone solubilized depends on the concentration of a surfactant and their flow rate, different percentages of Triton X-100 solution (1-10\%) and flow rates $\left(0.40-0.76 \mathrm{~mL} \mathrm{~min}^{-1}\right)$ were tested in order to obtain a suitable concentration of dithizone. The optimum values were $5 \%$ and $0.54 \mathrm{~mL} \mathrm{~min}{ }^{-1}$ respectively. In this way the reagent solution was obtained on-line.

The stability of the signal produced by on-line Dithizone preparation was verified and we conclude that it is stable for some days and 350 samples per column can be analysed.

To ensure the optimum medium ( $\mathrm{pH}$ 13) for Dithizone-Cd complex formation, different concentrations of $\mathrm{NaOH}\left(0.3-0.6 \mathrm{~mol} \mathrm{~L}^{-1}\right)$ were tested and it was selected $0.5 \mathrm{~mol} \mathrm{~L}^{-1}$.

The range of the studied variables and their optimum values are listed in Table 1.

\section{Analytical Performance}

The calibration graph showed to be linear over the range 6$300 \mu \mathrm{g} \mathrm{L}{ }^{-1} \mathrm{Cd}(\mathrm{II})\left(\mathrm{A}=0.015 \pm 0.002+0.943 \pm 0.001\left[\mathrm{Cd}(\mathrm{II}) \mu \mathrm{g} \mathrm{mL} \mathrm{L}^{-1}\right]\right.$;

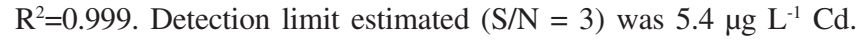
The relative standard deviation calculated for $\mathrm{n}=10$ samples containing $0.1 \mathrm{mg} \mathrm{L}^{-1} \mathrm{Cd}$ (II) injected by duplicate was $3.7 \%$. The sample throughput was $11.4 \mathrm{~h}^{-1}$. 
Table 1. Optimisation of chemical and FIA variables

\begin{tabular}{lcc}
\hline Variable & $\begin{array}{c}\text { Studied } \\
\text { range }\end{array}$ & $\begin{array}{c}\text { Optimum } \\
\text { value }\end{array}$ \\
\hline $\mathrm{HCl}[\mathrm{M}]$ & $0.2-3.0$ & 1.0 \\
$\mathrm{HCl} *[\mathrm{M}]$ & $0.1-0.5$ & 0.2 \\
$\mathrm{NaOH}[\mathrm{M}]$ & $0.3-0.6$ & 0.5 \\
$\mathrm{Diluent} \mathrm{flow} \mathrm{rate} \mathrm{q}_{2}\left[\mathrm{~mL} \mathrm{~min}^{-1}\right]$ & $0.40-1.10$ & 0.76 \\
$\mathrm{HCl} \mathrm{0.2} \mathrm{M,} \mathrm{sample} \mathrm{and}$ & $0.76-2.10$ & 1.10 \\
$\mathrm{NaOH} \mathrm{0.5} \mathrm{M} \mathrm{flow} \mathrm{rate} \mathrm{q}_{3}\left[\mathrm{~mL} \mathrm{~min}^{-1}\right]$ & & \\
Length of the column [cm] & $2.0-4.0$ & 3.0 \\
Inner diameter of the column [mm] & 2.0 and 4.0 & 4.0 \\
Regenerate column time [min] & $1.0-3.0$ & 2.0 \\
Sample loaded time [min] & $0.5-4.0$ & 3.0 \\
\hline
\end{tabular}

${ }^{*} \mathrm{HCl}$ for the mini-column regeneration

The enhancement factor (EF) to evaluate the preconcentration system, was calculated as the ratio of the slopes of the calibration curves before and after the preconcentration treatment ${ }^{12}$ and the obtained result was 6.5 .

\section{Interferences}

The effect of potential interferents on the determination of $100 \mu \mathrm{g} \mathrm{L}^{-1}$ of $\mathrm{Cd}(\mathrm{II})$ was studied. The tolerance limit was taken as the amount that caused an error of $5 \%$ in the absorbance. The common ions, which usually are present in water samples, do not interfere (Table 2). In order to eliminate up to $2 \mathrm{mg} \mathrm{L}^{-1}$ of $\mathrm{Fe}^{3+}, \mathrm{NaF}$ was added till its concentration is $5 \mathrm{mg} \mathrm{L}^{-1}$.

\section{Determination of cadmium in water samples}

The proposed method for the determination of cadmium was applied to superficial, well and drinking water samples. There was not present cadmium in them, so they were spiked with standard cadmium solution.

In order to validate the results obtained with the developed flow injection system the samples were analysed by ICP-AES. Sodium fluoride solution was added to the samples in order to eliminate the possible Fe(III) interference. The recovery values are shown in Table
Table 2. Interfering ions tolerance limits

\begin{tabular}{lc}
\hline Ion tested & Tolerance limit $\left(\mathrm{mg} \mathrm{L}^{-1}\right)$ \\
\hline $\mathrm{Cu}^{2+}$ & 1 \\
$\mathrm{Hg}^{2+}$ & 0.5 \\
$\mathrm{~Pb}^{2+}$ & 0.5 \\
$\mathrm{Mg}^{2+}$ & 100 \\
$\mathrm{Ca}^{2+}$ & 160 \\
$\mathrm{Ni}^{2+}$ & 1 \\
$\mathrm{Fe}^{3+}$ & Interfere \\
$\mathrm{Na}^{+}$ & 350 \\
$\mathrm{~K}^{+}$ & 500 \\
$\mathrm{~F}^{-}$ & 5 \\
$\mathrm{Cl}^{-}$ & 500 \\
$\mathrm{NO}_{2}^{-}$ & 1 \\
$\mathrm{NO}_{3}^{-}$ & 400 \\
$\mathrm{SO}_{4}{ }^{-}$ & 600 \\
\hline
\end{tabular}

${ }^{a}$ This interference is eliminated adding $\mathrm{F}^{-}$.

3. A $t$ test to evaluate the recoveries was used. The results revealed no significant differences between the obtained percentages and $100 \%$.

In order to compare the concentration obtained for the proposed method with that obtained for the reference method, an hypothesis test for two paired samples was applied ${ }^{13}$. The calculated $t$ value was less than $t$ from the table $\left(t_{\text {calculated }}=1.46\right.$ and $\left.t_{\text {critic }(95 \%, 11)}=2.205\right)$ which showed that there was no significant difference between both methods for the determination of cadmium in water samples.

\section{CONCLUSIONS}

A simple, highly sensitive and not so expensive automated method was developed and successfully applied to the determination of Cd(II) in natural, well and drinking water samples. The system involves a preconcentration step and the reagent preparation on-line. The method gives a good sensitivity and selectivity, good reproducibility and an acceptable sample throughput. The detection limit $\left(5.4 \mathrm{mg} \mathrm{L}^{-1}\right)$ is better than other previously reported ${ }^{3,4,9}$. The obtained results for the proposed method was compared with those obtained by ICP$\mathrm{AES}$ and it was statistically proved that they present good agreement.

Table 3. Recovery from Cd(II) added to natural water samples

\begin{tabular}{|c|c|c|c|c|c|}
\hline \multirow[t]{2}{*}{ Sample } & \multirow{2}{*}{$\begin{array}{c}\text { Cadmium added } \\
{\left[\mathrm{mg} \mathrm{L}^{-1}\right]}\end{array}$} & \multicolumn{2}{|c|}{$\mathrm{Cd}$ (II) found [mg L $\left.{ }^{-1}\right]$} & \multicolumn{2}{|c|}{ Recovery $\pm \mathrm{s}[\%] *$} \\
\hline & & Proposed method & $\begin{array}{l}\text { Reference method } \\
\quad \text { (ICP-AES) }\end{array}$ & Proposed method & $\begin{array}{l}\text { Reference method } \\
\text { (ICP-AES) }\end{array}$ \\
\hline $1-6$ & 0 & ns & ns & - & - \\
\hline 1 & 0.021 & $0.021_{1}$ & $0.021_{6}$ & $100.5 \pm 3.1$ & $102.3 \pm 2.0 *$ \\
\hline 1 & 0.210 & $0.209_{3}$ & $0.210_{0}^{\circ}$ & $99.6 \pm 1.5$ & $100.0 \pm 4.1$ \\
\hline 2 & 0.021 & $0.021_{3}$ & $0.021_{6}$ & $101.4 \pm 1.5$ & $102.3 \pm 1.5$ \\
\hline 2 & 0.210 & $0.206_{3}^{3}$ & $0.205_{0}^{6}$ & $98.2 \pm 2.1$ & $97.6 \pm 4.4$ \\
\hline 3 & 0.021 & $0.021_{0}$ & $0.021_{2}$ & $100.0 \pm 1.5$ & $100.9 \pm 2.3$ \\
\hline 3 & 0.210 & $0.216_{4}$ & $0.206_{0}^{2}$ & $103.0 \pm 2.1$ & $98.1 \pm 1.6$ \\
\hline 4 & 0.021 & $0.020_{5}$ & $0.021_{9}$ & $97.6 \pm 2.53$ & $104.2 \pm 4.2$ \\
\hline 4 & 0.210 & $0.210_{8}$ & $0.201_{0}$ & $100.4 \pm 1.4$ & $95.7 \pm 2.1$ \\
\hline 5 & 0.021 & $0.021_{3}^{\circ}$ & $0.020_{9}$ & $101.4 \pm 1.0$ & $104.2 \pm 1.6$ \\
\hline 5 & 0.210 & $0.205_{3}$ & $0.200_{2}$ & $97.8 \pm 1.6$ & $95.3 \pm 4.6$ \\
\hline 6 & 0.021 & $0.021_{4}$ & $0.021_{8}$ & $101.9 \pm 3.0$ & $103.8 \pm 2.6$ \\
\hline 6 & 0.210 & $0.211_{5}$ & $0.207_{6}$ & $100.7 \pm 4.6$ & $98.9 \pm 1.0$ \\
\hline
\end{tabular}

ns: no signal; *Standard deviation $(\mathrm{n}=3)$ 


\section{ACKNOWLEDGEMENTS}

The authors express their gratitude to the Consejo Nacional de Investigaciones Científicas y Técnicas (CONICET) de la República Argentina for the financial support.

This work was partially supported by the Universidad Nacional del Sur, Bahía Blanca, Argentina.

\section{REFERENCES}

1. Sastre, J.; Sahuquillo, A.; Vidal, M.; Rauret, G.; Anal. Chim. Acta 2002, $59,462$.

2. Melo, M. H. A.; Ferreira, S. L. C.; Santelli, R. E.; Microchem. J. 2000, 65,59 .

3. Anthemidis, A. N.; Zachariadis, G. A.; Farastelis, C. G.; Stratis, J. A.; Talanta 2004, 62, 437.
4. Boevski, I.; Daskalova, N.; Havezov, I.; Spectrochim. Acta, Part B 2000, 55, 1643.

5. Álvarez-Llamas, G.; Fernández de la Campa, M. R.; Sanz-Medel, A.; Anal. Chim. Acta 2001, 448, 105.

6. Paradkar, R. P.; Williams, R. R.; Anal. Chem. 1994, 66, 2752.

7. Romberg, B.; Müller, H.; Anal. Chim. Acta 1997, 353 , 165.

8. Yuanqian, L.; Jingmei, H.; Jingguo, Y.; Bo, Z.; Yuanqing; H.; Anal. Chim. Acta 2002, 461, 181.

9. Hashem, E. Y.; Spectrochim. Acta, Part A 2002, 58, 1401.

10. Samuelson, O.; Ion Exchange Separations in Analytical Chemistry, John Willey Sons. Ed.: New York, 1963.

11. Berg, E. W.; Truemper, J. T.; Anal. Chem. 1958, 30, 1827.

12. Fang, Z.; Flow Injection Separation and Preconcentration, VCH Ed.; Weinheim Germany, 1993, p. 12.

13. Massart, D. L.; Vandeginste, B. G. M.; Buydens, L. M. C.; De Jong, S.; Lewi, P. J.; Smeyers-Verbeke, J.; Handbook of Chemometrics and Qualimetrics: part A, Elsevier Science B.V. Ed., 1997, p. 98. 